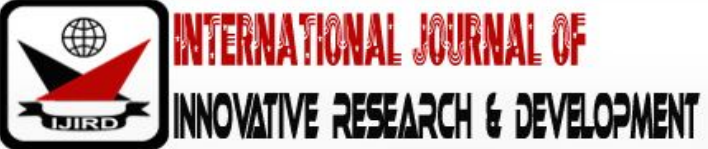

ISSN 2278 - 0211 (Online)

\section{An Assessment of the Impact of Property Maintenance on Property Rental Values in D-Line Port Harcourt, Nigeria}

\author{
Ernest Usua Effiong \\ Research Student, Department of Etate Management, Rivers State University, Port Harcourt, Nigeria \\ Ebiwari Wokekoro \\ Lecturer, Department of Etate Management, Rivers State University, Port Harcourt, Nigeria
}

\begin{abstract}
:
The study investigates the impact of property maintenance on property rental values in Port Harcourt: A case study of D/ line Housing. The population of the study consists of 119 firms of estate surveyors and valuers practicing in Rivers State and 230 tenants occupying blocks of 2 and 3 bedroom flats in the study area. This was selected through purposive sampling techniques with sample size of 238 respondents using the Taro Yamane formular. Three research questions were answered. Data were collected through the administration of a questionnaire. A total of 238 questionnaires were distributed to the sample groups, out of which 210 were retrieved representing $89 \%$ response which was found useful for the analysis. Data obtained were analyzed using percentage, mean, and chart. The result from the analysis showed that preventive maintenance practices are adopted in property maintenance to enhance its value. The study further revealed that lack of sufficient funds is the most prevalent factor that affects property maintenance. The mean from the study also revealed that roof is the most significant element that will impact on property rental values. The study also revealed that rental values of well-maintained properties are higher than the poorly maintained properties. The study concludes that maintenance of property requires attention at the highest level. Therefore, maintenance of properties should not be neglected by owners and users. The study recommends that preventive maintenance practices should be adopted by property managers to ensure adequate preservation of the building and its elements to enhance its values. Some percentage of rent should be set aside annually to prevent lack of sufficient fund to carryout maintenance.
\end{abstract}

Keywords: Impact, maintenance, rental values, residential properties

\section{Introduction}

Building maintenance is an important program for the sustainability of infrastructural development. It plays a central role among other activities in the building operations (Zulkarnain et al, 2011) cited in Baba, and Buba, (2013). Maintenance has been defined by various authors. Maintenance according to British Standard (BS 3811) (1984) is the combination of all technical and associated actions intended to retain an item or restore it to a state in which it can perform its required function. Maintenance is also seen as work carried out to keep, restore or improve every part of a building, its services and surrounds to a currently acceptable condition (Williams, 1994). Smith (2003) stated that maintenance is defined to keep the building in its existing state and in high quality operating condition and preserve. The definitions of the maintenance are always related to the building, to the extent that the building shall be good enough to allow the occupants to use their functions, because it is a source of value that design to provide necessary services of daily activities (Lateef, 2010). Maintenance has to perform effectively in buildings due to building cannot remain zero defects throughout their lifespan. The need for maintenance will be intensified, especially for aged buildings because of the need to replace or repair more components which have reached their useful lifespan. Therefore maintenance is considered as an essential activity where it can provide support to the buildings lifespan and maintains the value of asset of the country (Yong and Sulieman, 2015). In general, the main objectives of building maintenance are to retain a building in its original state, as far as possible to serve it function wisely to an appropriate condition (Al-zubaidi etal, 1997). The task of the maintenance includes servicing, inspection, replacement, renovation and overhaul. Work carried out in expectation of failure is referred to as preventive maintenance, and those carried out for restoring after failure is referred to as corrective maintenance (Baba and Buba, 2013). It is well-known fact that the primary objective of building maintenance is to preserve buildings in their initial functional, structural and aesthetic states (Adejimi, 2015). Maintenance program in Nigeria for instance, according to Ahmed (2000) and Odediran et al, (2012) has not received much attention in the past as the emphasis is on the development of new properties. Kunya et al, (2007) also observed that there is apparent lack of maintenance culture in Nigeria, and that emphasis is placed on the construction of new buildings and neglecting the aspect of maintenance which commences immediately the builder leaves the site. This is also supported by Olagunju (2012) who opined that there is lack of maintenance set up in Nigeria that can sustain the current inadequate housing provision in the 
country. Olagunju (2012) further stated that lack of appropriate tool for predictive maintenance of the existing buildings can have a detrimental effect on future housing development. Zubairu (1998) stated in his study that the country does not have a maintenance policy which resulted in the persistent problems of building maintenance.

Rental values of properties vary from place to place depending on various factors among which facilities availability stand prominent (Akogun, 2011). The study seeks to investigate the impact of property maintenance on property rental values in $\mathrm{D} /$ line Port Harcourt. The objectives of the study are;

- Identify maintenance practices that can enhance property values.

- Identify factors affecting property maintenance

- Identify maintenance condition of building elements that will impact on the rental values of property.

\subsection{Description of the Study Area}

Port Harcourt is the capital and largest city of Rivers State, Nigeria. It lies along the Bonny River and is also located in the Niger Delta. As of 2016, the Port Harcourt Urban area has an estimated population of 1,865,000 inhabitants, up from 1,382,592 as of 2006(Ogwu and Chinedu, 2011). The area that became Port Harcourt in 1912 was before the part of the farmlands of the Diobu village group of the Ikwerre, an Igbo sub-group. The Colonial administration of Nigeria created the Port to export coal from the collieries of Enugu located 243 Kilometers (15 million) North of Port Harcourt to which it was linked by a railway called the Eastern line, also built by the British. There are a number of institutions of tertiary education in Port Harcourt mostly government owned. These institutions include, Rivers State University, University of Port Harcourt and Rivers State College of Art and Science currently now Rivers State Polytechnic and Rivers State College of Health Science and Technology.

D-line is a major business and urban residential neighborhood of Port Harcourt, Rivers State. Its geographical coordinates are $4^{\circ} 48^{\prime} 8^{\prime \prime}$ North, $700^{\prime} 10^{\prime \prime}$ East. The neighborhood is sometimes spelled "D/ LINE" with a ZIPCODE of 500261. The Roman Catholic Diocese of Port Harcourt and the Methodist Church of Nigeria have their Cathedrals situated in D-line. D-line is located approximately 5km (3miles) away from the Port Harcourt Nigeria Air force (NAF) Base, and approximately $8 \mathrm{~km}$ (5miles) South West of Elelenwo. There are elementary and secondary schools operating within D-line boundaries such as; Government Girls Secondary school, Oromineke, Methodist comprehensive High School and Niger Grammar School.

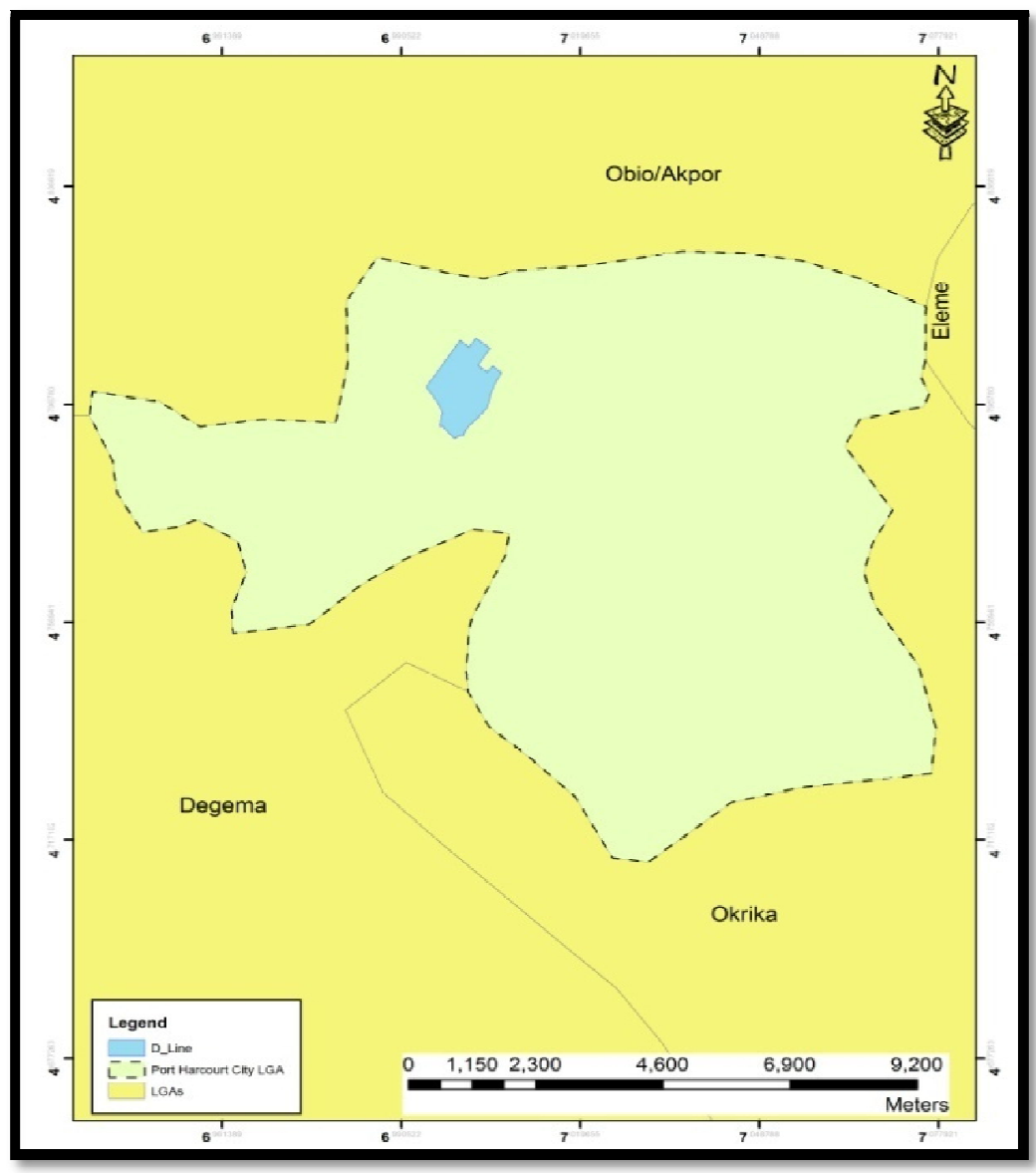

Figure 1: Map of Port Harcourt City Showing D/ Line

(Isiodu and Sokari, 2017) 


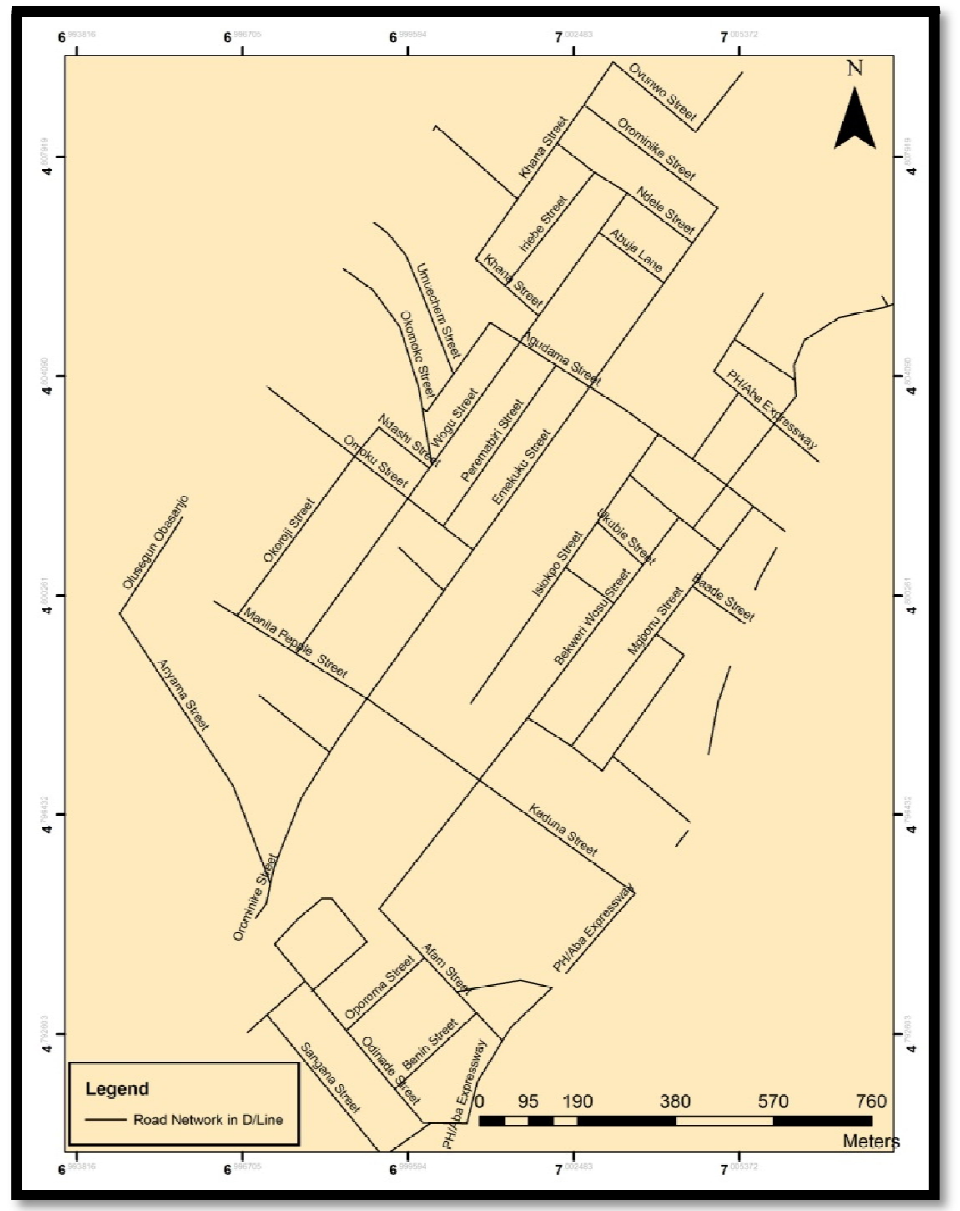

Figure 2: Map Showing Streets in D/ Line Port Harcourt (Isiodu and Sokari, 2017)

\section{A Brief Review of Related Literature}

\subsection{Concept of Rental Value}

Value by its ordinary definition particularly in basic economics, means the amount of money that something is worth that is, the price it can command if sold at a given date. With respect to real estate, value means worth of an interest in land or, land and building or claims on chattels assessed by appropriate method of valuation. Rental value is defined as the amount the property is eligible to get had it been rented out as per the prevailing situations existing in that for similar property. Rental value is the fair market value of property while rented out in a lease. More generally, it may be the consideration paid under the lease for the right to occupy, or the royalties or return received by a lessor (landlord) under a license to real property. In the science and art of appraisal, it is the amount that would be paid for rental of similar real property in the same condition and in the same area (Wikipedia, 2007).

Adeniji (2000) emphasized that value is normally expressed in monetary terms, which indicates the power of a commodity to command other commodities in exchange. Kuye (2000) defined rent as "an annual or periodic payment for the use of land or of land and building". He regards rent as a compensation or regular payment made to the owner of the property by the user or occupier as return for his occupancy - Rent is seen an annual or periodic payment for the use of land or building (Britten et al, 1989). In fixing the rent of a property, a valuer is largely influenced in practice by the evidence he can find, the rent actually paid, not only for the property being valued but also for comparable properties in the same neighborhood or area. However, "rent" is generally used in relation to land and building while "hire" is normally used for other material objects. The rent payment could be weekly, monthly, quarterly or yearly depending on the terms and condition of the tenancy.

\subsection{Concept of Property Value}

Real property is defined as land, buildings and other improvements there on and the legal right relating to the asset-land (Ekenta, 2010). However, this definition tends to be confusing as there is always a distinction between real property and real estate, though both terms are sometimes used interchangeably in real estate profession literature and practice (Schram, 2012). Real property is seen only as the interests, benefits, and rights inherent in the ownership of real estate, while real estate is defined as only the physical land and the improvements thereon (Schram, 2012). This dissimilarity clarify that real property cannot be both land and rights and that is the reason why most appraisers are concerned in the interest substituting in the property than the property per se. At the same time, the classification is according to their forms of ownership, use, etc., and which could be classified into possessory real property and non- 
possessory real property (Schram, 2012). The real property in any of its investment sector has the characteristics which are noticeable from other investments. However, Kalu (2001) identify the following characteristics to include; heterogeneity, risk, liquidity, and indivisibility. Others are; high cost of transfer, holding cost, income and capital growth, special ownership games, imperfect knowledge, perpetuity, and leverage or gearing. In other words, the discussion above is not out of place, but the study context is on property rental values.

\subsection{A Review of Related Studies}

Odediran etal; (2012) conducted a study on maintenance of residential buildings; users practice in Nigeria. The study examines maintenance practice among users of residential properties in Nigeria. In assessing how often maintenance practice is being undertaken by occupiers, it shows that users maintained their properties daily by undertaking regular sweeping and mobbing of the floor. The researcher further stated that economic factor prevents users from carrying out effective maintenance on buildings. The researcher therefore recommends that individual should embrace maintenance as a practice and government should engineer action towards more advocacy, policy and awareness on the maintenance as a practice for national sustainability.

Ankeli et al; (2015) focus on housing condition and residential property rental values in Ede, Nigeria. Two sets of questionnaire were distributed to tenants/ landlords of rented residential properties and estate surveyors and valuers. A total of 300 questionnaires were administered on the respondent using systematic Random sampling techniques. The data collected were further analyzed with the aid of both descriptive and inferential analytical techniques. The researcher stated that properties with better conditions in terms of infrastructures and physical soundness command higher rental values that investment in residential property development will in the next three years continue to enjoy and maintain an upward growth rate. In the recommendation it was suggested that there is need for property owner / developers and users to be educated on the need for the provision of basic infrastructure and sustainable maintenance culture. He further recommended that government should make policies aimed at defining environmental housing quality standard and provide supervisory agency that will be responsible for the monitoring and implementation of housing standards.

According to Siyanbola et al, 2013 maintenance of building received little attention from the users, designers and contractor's. It should be noted that the maintenance purpose is to preserve buildings in their initial functional, structural and aesthetic states. This is to ensure that they continue to remain in such state and retain their investment value over a long period of existence (Ipingbenu, 2010).

Ihuah et al; (2014) conducted a comparative study on two residential estates (Agbama and Ehimiri) in Umuahia, Nigeria the study was based on assessing the impact of inadequate infrastructures provision on real property values. Questionnaires were distributed to housing units residents/ tenants and landlords of estate that have been completed and occupied. The study revealed that there are better infrastructural provisions in Ehimiri housing estate as compared to Agbama housing estate. The study further analyzed the rental trends of the two housing estates from 2007 to 2014. However, in his recommendation it was suggested that an empirical investigation should be conducted on the causes of inadequate infrastructures provision identified in the theoretical framework. This assists to establish if these causes would have stronger association with these known infrastructures and then the probability of either positively or negatively influencing property value of housing estate units.

Talib et al; 2014 study on the Assessment of factors affecting building maintenance and defects of public buildings in Penang, Malaysia. The data for the research work was obtained through the administration of structured questionnaire. In analysis of data collected, the descriptive statistics was used to analyze the demographic data of the respondents while it was used to analyze the respondent's score of the basic maintenance and defect factors. The researcher stated that 5 major factors affecting building maintenance of public buildings are; lack of preventive maintenance, insufficient funds, lack of building maintenance standard, non - response to maintenance request. In further, state 5 factors of building defects which were ranked as most significant factors which are; lack of building maintenance, over looked site conditions, defective material, environment conditions and moisture from wet areas.

\section{Research Methods}

The study was conducted on tenant occupying residential properties (blocks of 2 and 3 bedroom flats) in D/ line Port Harcourt and registered firms of estate surveyors and valuers practicing in Rivers state. The total target population for the study is 119 firms and 230 tenants in the study area. This was selected through a purposive sampling technique with a sample size of 92 firms and 146 tenants with the aid of the taro Yamane formular. A total of 238 questionnaires were distributed to the sample groups, out of which 210 were retrieved representing $89 \%$ response rate which was found useful for analysis. Data collected for the study was analyzed through the use of percentage, mean and line graph.

\section{Result and Discussions}

The results from the study are presented below

\subsection{Types of Maintenance Practice Adopted}

Table 4.1 presents data on the type of maintenance practice adopted by estate firms. Preventive maintenance has the highest frequency of 33 (41.3\%), followed by scheduled maintenance with 27 (33.7\%), emergency maintenance with $12(15.0 \%)$ and corrective maintenance with 8 (10.0\%) respectively. 


\begin{tabular}{|c|c|c|}
\hline Responses & Frequency & Percent \\
\hline Preventive & 33 & 41.3 \\
\hline Emergency & 12 & 15.0 \\
\hline Corrective & 8 & 10.0 \\
\hline Scheduled & 27 & 33.7 \\
\hline Total & 80 & 100.0 \\
\hline
\end{tabular}

Table 1: Types of Maintenance Practice Adopted

Source: Author's Field Work 2017

\subsection{Factors that will affect Property Maintenance}

In table 4.2, the factors that affect property maintenance were examined and ranked with lack of sufficient fund ranked first with mean value of 4.6625 . It shows that lack of sufficient funds affect property maintenance the most. Ranked second is lack of preventive maintenance with mean value of 4.4750 , third is not using of building after completion with mean value of 4.2375, fourth is lack of building maintenance manual with 4.2125 mean, fifth is design complexity with 4.1833 mean, sixth is owners attitude to building maintenance with 4.0125 mean, ranked seventh is wrong behaviour of occupant with mean of 3.6375 and ranked eighth is use of substandard materials with mean of 3.5250 .

\begin{tabular}{|c|c|c|c|c|c|c|c|c|}
\hline Factors & SA & $\mathbf{A}$ & $\mathbf{U}$ & $\mathbf{D}$ & $\mathbf{S D}$ & $\mathbf{F}$ & $\begin{array}{c}\text { Mean } \\
\text { Score }\end{array}$ & Rank \\
\hline Lack of preventive maintenance & 45 & 30 & 3 & 2 & - & 80 & 4.4750 & $2^{\text {nd }}$ \\
\hline Lack of sufficient funds & 54 & 25 & 1 & - & - & 80 & 4.6625 & $1^{\text {st }}$ \\
\hline Use of substandard materials & 25 & 20 & 15 & 12 & 8 & 80 & 3.5250 & $8^{\text {th }}$ \\
\hline Not using building after completion & 33 & 30 & 6 & 3 & 5 & 80 & 4.2375 & $3^{\text {th }}$ \\
\hline $\begin{array}{c}\text { Owner's attitude to building } \\
\text { maintenance }\end{array}$ & 30 & 35 & 5 & 6 & 4 & 80 & 4.0125 & $6^{\text {th }}$ \\
\hline $\begin{array}{c}\text { Wrong behaviour of occupants } \\
\text { Design complexity }\end{array}$ & 28 & 25 & 5 & 14 & 8 & 80 & 3.6375 & $7^{\text {th }}$ \\
\hline Lack of building maintenance manual & 38 & 25 & 5 & 5 & 5 & 80 & 4.1250 & $5^{\text {th }}$ \\
\hline
\end{tabular}

Table 2: Factors That Will Affect Property Maintenance

$\mathrm{SA}=$ Strongly Agree, $\mathrm{A}=$ =Agree, $\mathrm{U}=$ Undecided, $\mathrm{D}=$ Disagree, $\mathrm{SD}=$ Strongly Disagree

Source: Author's Field Work 2017

\subsection{Building Elements That Will Impact on Property Rental Values}

Table 3 below shows building elements that will impact on property rental values. The most building element ranked first is number of roof with mean score of 4.4846, ranked second is number of rooms with 4.3846 mean score, third is No of toilets with mean score of 4.3308. The fourth building element is number of bathrooms, fifth is floor damage, sixth is walls, seventh is sanitary fittings, eighth is door and window, ninth is peeling of wall surface, tenth is fence damage and eleventh is number of water heater respectively.

\begin{tabular}{|c|c|c|c|c|c|c|c|c|}
\hline Property Element & SA & $\mathbf{A}$ & $\mathbf{U}$ & $\mathbf{D}$ & $\mathbf{S D}$ & $\mathbf{F}$ & $\begin{array}{c}\text { Mean } \\
\text { Score }\end{array}$ & Rank \\
\hline Roof & 73 & 52 & 1 & 3 & 1 & 130 & 4.4846 & $1^{\text {st }}$ \\
\hline Door and window & 50 & 60 & 4 & 5 & 11 & 130 & 4.0231 & $8^{\text {th }}$ \\
\hline Walls & 63 & 50 & - & 7 & 10 & 130 & 4.1462 & $6^{\text {th }}$ \\
\hline Floor damage & 54 & 52 & 2 & 5 & 17 & 130 & 4.2385 & $5^{\text {th }}$ \\
\hline Sanitary fittings & 55 & 57 & 1 & 4 & 13 & 130 & 4.0538 & $7^{\text {th }}$ \\
\hline Peeling of wall surface & 45 & 51 & 2 & 17 & 4 & 130 & 3.9000 & $9^{\text {th }}$ \\
\hline Fence damage & 48 & 40 & 7 & 10 & 25 & 130 & 3.5846 & $10^{\text {th }}$ \\
\hline No. of rooms & 69 & 53 & - & 5 & 3 & 130 & 4.3846 & $2^{\text {nd }}$ \\
\hline No. of toilets & 65 & 55 & 2 & 4 & 4 & 130 & 4.3308 & $3^{\text {rd }}$ \\
\hline No. of bathrooms & 61 & 56 & 4 & 3 & 6 & 130 & 4.2538 & $4^{\text {th }}$ \\
\hline No. of water heater & 46 & 38 & 10 & 15 & 21 & 130 & 3.5615 & $11^{\text {th }}$ \\
\hline
\end{tabular}

Table 3: Building Elements That Will Impact on Property Rental Values

$\mathrm{SA}=$ Strongly Agree, $\mathrm{A}=$ =Agree, $\mathrm{U}=$ Undecided, $\mathrm{D}=$ Disagree, $\mathrm{SD}=$ Strongly Disagree

Source: Author's Field Work 2017 


\subsection{Rental Trends of Residential Properties (Block of Flats) in D-line}

Table 4.4 presents data on rental value of poorly and well maintained properties within the neighbourhood of DLine in Port Harcourt. The Results of the data show that rental values of well-maintained properties are higher than that of poorly maintained properties as shown in table 4 for 2 bedroom and 3 bedroom flats. The study has shown from the graph below on the rental growth trend of poorly and well maintained properties in D/ line from 2013-2017. The rental values of poorly maintained 2 bedroom flat for 5 years period ranges from $\# 300,000-\# 450,000(\$ 824.5-\$ 1,236.8)$ while well maintained flatsranges from $\# 400,000-\# 600,000(\$ 1,099.3-\$ 1,649)$. It therefore shows a difference of \#100,000$\# 200,000$ (\$274.8-\$549.6) rental growths in each year due to good maintenance practices on the building and its elements. On the other hand, the rental values of poorly maintained 3-bedroom flats over the same period ranges from \#450,000$\# 550,000$ (\$1,236.8-\$1,511.6) while well maintained3-bedroom flats ranges from \#600,000-\#800,000 $(\$ 1,649-\$ 2,198.7)$. From the graph it indicates a rental growth difference of $\# 150,000-\# 250,000$ (\$412.2-\$687.1) in each year as a result of adequate maintenance on the property. However, existing tenant of such property will be willing to renew their tenancy after expiration due to high level of satisfaction they derived as a result of a good maintenance practices. These properties can easily be let out to prospective tenants. On the other hand, the poorly maintained property affects the rental growth of the investment property due to neglect in carrying out proper maintenance on the building and its elements. These properties may be difficult to let out and during management.

\begin{tabular}{|c|c|c|c|c|}
\hline Years & $\begin{array}{c}\text { Rental Values of } \\
\text { Poorly Maintained } \\
\text { Flats }\end{array}$ & $\begin{array}{c}\text { Rental Values of } \\
\text { Well-Maintained } \\
\text { Flats }\end{array}$ & $\begin{array}{c}\text { Rental Values of } \\
\text { Poorly Maintained } \\
\text { Flats }\end{array}$ & $\begin{array}{c}\text { Rental Values of } \\
\text { Well-Maintained } \\
\text { Flats }\end{array}$ \\
\cline { 2 - 5 } & 2 bedroom & 2 bedroom & 3 bedroom & 3 bedroom \\
\hline 2013 & 300,000 & 400,000 & 450,000 & 600,000 \\
\hline 2014 & 300,000 & 500,000 & 500,000 & 650,000 \\
\hline 2015 & 400,000 & 500,000 & 500,000 & 650,000 \\
\hline 2016 & 400,000 & 600,000 & 550,000 & 800,000 \\
\hline 2017 & 450,000 & 600,000 & 550,000 & 800,000 \\
\hline
\end{tabular}

Table 4: Rental Trends of a Well and poorly Maintained Properties Source: Author's Field Work 2017

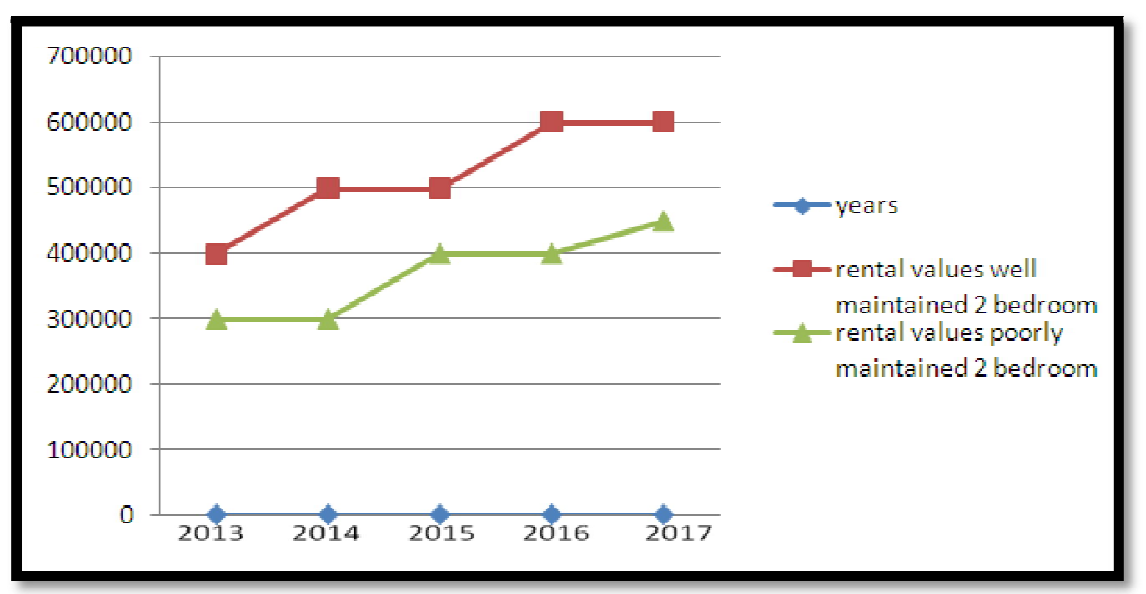

Figure 3: Rentals Trends for Well and Poorly Maintains 2 Bedroom Flats From 2013-2017

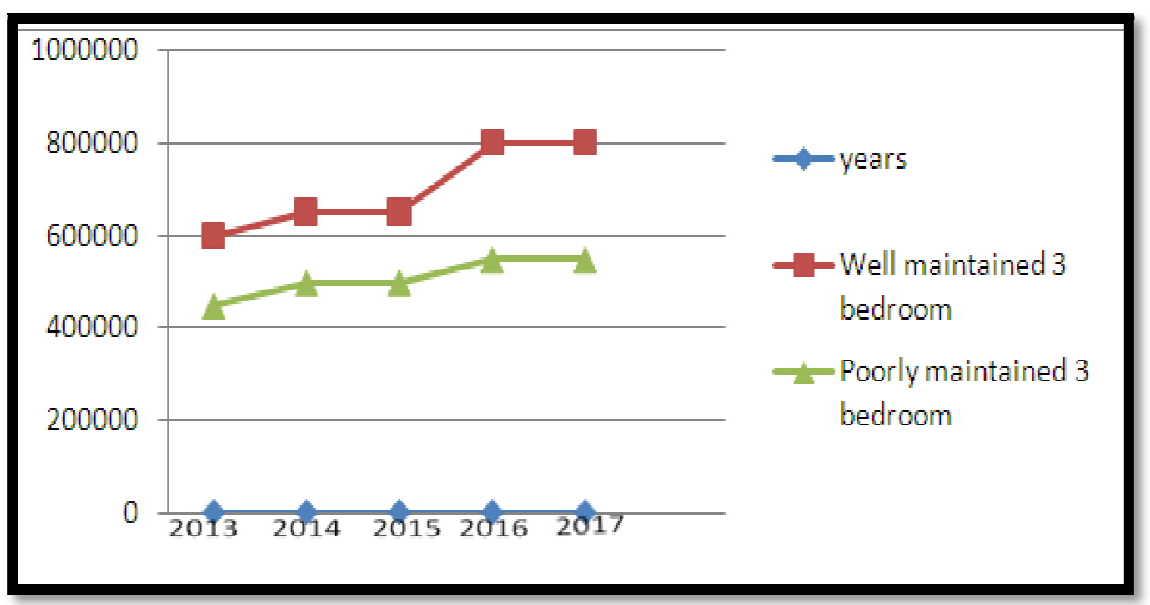

Figure 4: Rentals Trends for Well and Poorly Maintains 3 Bedroom Flats from 2013-2017 


\section{Conclusion and Recommendations}

Maintenance of building requires attention at the highest level. This attention is of basic significance of which the objective must be to keep the building and its elements to acceptable standard for the purpose of making them functional and reliable. Poor attitude of owner's and users towards maintenance contribute to serious defects seen in the life span of buildings.

The study is essential in the sense that it would not only contribute to knowledge but will also contribute to good maintenance practice among owner's and users of properties in Port Harcourt most especially D/ line where the study was carried out. However, the study showed that property maintenance have positive impact on property rental values in essence maintenance should not be neglected, in addition it will further reduces the shortage of housing stock in the country. The study recommended that preventive maintenance practices should be adopted by property managers to ensure adequate preservation of the building elements as it enhances property values and owners should set aside some percentage of the rent paid on the property annually to carry out maintenance when required.

\section{References}

i. Adejimi, A., (2005). Poor Building Maintenance are Architects Free from Blames? A Paper Presented at the ENHR International Conference on Housing; New Challenges and innovations in Tomorrow's Cities. Iceland.

ii. Adeniyi S. A. (2000). The Applications of the Principles and Methods of Valuation inNigeria. MTC Publications, Ibadan, Nigeria: 1-203.

iii. Ajibola M. O, Awodiran O. O, Salu-Kosoko O. (2013). Effects of Infrastructure on Property Values in Unity Estate, Lagos, Nigeria. International Journal of Economy, Management and Social Sciences, 2(5), 195-201.

iv. Ankeli, A.I. \& Dabara, D.I. (2015). Housing Condition and Residential Property Rental Values in Ede Nigeria. International Journal of Arts and Sciences: 53 - 61.

v. Ankeli, I.A., Dabara, D.I., Gambo, M.D \& Lawal, K.O. (2016). Residential Housing Rental Values and Infrastructural Development in Osogbo, Nigeria. International Journal of Art \& Sciences:29-40

vi. Baba, S. W. \& Buba, A. V. (2013). Evaluation of Factors Affecting Residential Building Maintenance in Nigeria: Users' Perspective. Civil and Environmental Research, No.8, available at www.iiste.org. Retrieved on September, 2014.

vii. British Standard Institution (1984). BS3811.Glossary of Maintenance Management Terms in Technology. London.

viii. Britton W., Davis K. \& Johnson T. (1989). Modern Methods of Valuation of Land, Houses and Buildings. Eighth Edition, Estate Gazette Limited, London: 1 -726.

ix. Isiodu, E. R \& Sokari, B. S (2017). Goes Konsoult.

x. Ekenta, E. (2010). Basic Theory and Application of Modern Valuation; Alheri Books, Port Harcourt, Nigeria

xi. Kalu, I. U. (2001). Property Valuation and Appraisal; Bon Publications, Owerri.

xii. Kuye O. (2000). Property Valuation: Principles and Practice in Nigeria. AIL, Lagos: 1-343.

xiii. Lateef. (2010). Case for Alternative Approach to Building Maintenance Management of Public Universities. Journal of Building Appraisal. 5(3): 201-212.

xiv. Ogwu, A. \& Chinedu, L. (2011). "Port Harcourt PDP Rally Stampede: Irregular Or Action?". Nigerians In America. Retrieved 25 June 2014.

xv. Odediran, S.J., Opatuni, A.O. \& Eghenure, F.O (2012). Maintenance of Residential Buildings: Users Practices in Nigeria.Journal of Emerging Trends in Economics and Management Sciences: Pg 261 - 265.

xvi. Olagunju, R.E., (2012). Predictive Modelling for Sustainable Residential building Maintenance in Developing Countries: A Nigerian Case. Interdisciplinary Journal of Contemporary Research in Business. 4(6), 1237-1283.

xvii. Rental Value, http:/ / en.wikipedia.org/ wiki/ real estate estate.

xviii. Schram, J.F.Jr. (2012). Real Estate Appraisal, Sixth Edition, Rockwell Publishing, USA.

xix. Smith. R (2003). Best Maintenance Practices; Journal for Maintenance and Maintenance Management, 16(1).

xx. Woka, I.P., Chukwuemeka, E. \& Nwokorie, B. (2014). Impact of Inadequate Infrastructures Provision on Real Property Value: A Comparative Study of Agbama and Elimiri Housing Estate, Umuahia Nigeria. International Journal of Environment, Ecology, Family and Urban Studies, Vol. 4.

xxi. Zulkarnain, S.H., Zawani, E.M.A., Rahman, M.Y.A and Mustafa, N.K.F. (2011). A Review of Critical Success factor in Building Maintenance Management Practice for University Sector. World Academy of Science, Engineering and Technology. 53:195-199. 